\title{
A career in biophysics
}

\author{
Cris dos Remedios ${ }^{1}$
}

Received: 18 June 2020 / Accepted: 2 July 2020 / Published online: 9 July 2020

(C) International Union for Pure and Applied Biophysics (IUPAB) and Springer-Verlag GmbH Germany, part of Springer Nature 2020

\begin{abstract}
My career in science started with my PhD under Professor Darcy Gilmour at the University of Sydney. I quickly learned his iconoclastic ways and completed the degree in early 1969 in just over three years. Professor Charles Birch was the Head of Zoology and had been watching my progress and offered me a position as Lecturer as soon as my $\mathrm{PhD}$ was submitted. He asked me to set up a new course on invertebrate physiology, and the salary enabled me to afford the airfare to San Francisco for my family. In December 1969, I headed to the University of California San Francisco to work with Manuel Morales in the renowned Cardiovascular Research Institute headed by Julius Comroe (1965), the author of the textbook of pulmonary physiology, The Lung. I had a great time there meeting many important scientists that I had only read about, including Setsuro Ebashi, Andrew Huxley, Fumio Oosawa and Bernard Katz who had just won his Nobel Prize. It was inspiring. For the next two and a half years, I immersed myself in fluorescence polarisation spectroscopy, and rubbed up against with some of the best minds in the muscle field including Roger Cooke. Manuel Morales sent Roger to collect this Aussie and his family, and we have remained friends ever since.
\end{abstract}

\section{The Louis N Katz prize}

In 1971, I had the good fortune to be awarded the Louis N Katz Prize of the American Heart Association for Young Investigators for my first big manuscript (dos Remedios et al. 1972). Later, this manuscript was selected by the Editors of Journal of Muscle Research and Cell Motility inclusion in the list of 50 outstanding contributions to muscle research since the publications by AF Huxley and J Niedergerke and by HE Huxley and J Hanson in Nature in 1954. The news of this prize quickly spread back to Sydney, and in 1972 I was offered a Senior Lectureship in human anatomy at the University of New South Wales which I gratefully accepted. But then two years later, the head of the Department Professor Michael Blunt moved to the University of Sydney and invited me to follow him.

Cris dos Remedios

cris.dosremedios@sydney.edu.au

1 Molecular Cardiology and Biophysics, Victor Chang Cardiac Research Institute, Lowy Packer Building, 405 Liverpool Street, Darlinghurst 2020, Australia

\section{The Muscle Research Unit}

In 1974, I established the Muscle Research Unit at the University of Sydney. I focused on the structure and function of the muscle protein actin. This ubiquitous protein is expressed in significant quantities (10\% of total protein) in all cells and represents about $30 \%$ of the total contractile proteins in muscle. This research was initially funded (1975) by the National Heart Foundation and the ARC, but soon I had several concurrent project grants funded by the NHMRC that continued for three decades. I published the first images of actin monomer using two-dimensional crystals of actin (dos Remedios and Dickens, 1978), and over the next 20 years I published over 60 papers on actin and actin-binding proteins. Much of my focus was using fluorescence resonance energy transfer (FRET) spectroscopy to map intramolecular and intermolecular distances of actin of myosin. Sceptics of FRET believed that assuming the value of kappa $\left(k^{2}\right)$ to be $2 / 3$ relied on the assumption that both donor and acceptor probes could freely precess. They argued that covalently binding these probes to surface amino acids would restrict probe movements; therefore, $k^{2}$ was "unknown". In 1995, we (dos Remedios and Pierre Moens) put that argument to rest, not only by citing scores of papers where $k^{2}$ worked, but also by citing who demonstrated rotational freedom of peptide side 
chains (dos Remedios and Moens 1995). I also edited four books which arose from International Conferences I arranged devoted to advances in actin and actin-binding proteins. The last book (dos Remedios and Chhabra 2007) had 12,469 chapter downloads by 2017. However, my fascination with actin dwindled once the actin-DNaseI complex was crystallised; the atomic structure of actin was determined by Kabsch et al. in 1990.

\section{Dr Victor Chang}

In 1989 following a chance meeting, I began working with Dr Victor Chang, famous for his role in the development of human heart transplantation in Australia for which he was awarded the nation's highest honour Companion of the Order of Australia in 1986, and in 2000 he was named Australian of the Century. Although we worked together for only two years before he was murdered, Victor changed the course of my life from a protein chemist to a 30-year research program with the aim of trying to understand the molecular basis for human heart failure. Tragically, Victor was murdered on July 4, 1991. By then, my students and I had gotten used to getting up in the small hours of the morning to collect the hearts at St Vincent's Transplant Theaters. Also, I was travelling a lot in the US, UK, Japan and Europe developing close contacts with the muscle biophysics community through the Gordon Research conferences. My approach was simple. I believed that no one person could hope to get to the bottom of all forms of human heart failure, but as a community we could certainly make good progress.

\section{Sydney Heart Bank}

Today, the Sydney Heart Bank contains explanted hearts from over 350 patients. I am not overstating when I say the quality of the tissue from these patients was exceptional. All heart samples were snap-frozen in the theatres of the St Vincent's Hospital in liquid nitrogen. All parts of the heart were collected within 40 minutes of the "cross-clamp" when the heart loses its supply of arterial blood. Initially, we collected only a few samples from each of the four chambers of the heart, but soon we realised that other researchers also needed tissue, particularly from the left ventricles. Victor Chang was very encouraging but real progress was inhibited by the paucity of healthy donor hearts with which we could compare with the failing hearts. Healthy non-failing hearts were primarily used as donors in the Heart \& Lung Transplant Unit. However, every so often, a donor would become available with a tissue type that did not match any of the waiting patients. Gradually, we accumulated hearts that, for a variety of reasons, made them unsuitable as donors. Brain-dead donors often resulted from a motor vehicle accident (including motorcycles), but most arose from aneurisms or massive haemorrhages of the arteries that supply the brain. Others, particularly children, had drowned and been revived but with no brain wave activity. When there were no young patients waiting for a heart transplant, we collected the heart. Other donors sadly had taken their own lives. Over the decades, we have collected over 120 healthy donor hearts. None of these were post-mortem cases where tissue was not collected for 24 hours or more after death.

\section{Sydney Heart Bank Logistics}

Transportation of the heart samples around the world was achieved using nitrogen-vapour dewars. Airlines would not allow sufficient dry ice for a flight from Sydney to the West Coast of the USA. Our dewars could maintain $-190{ }^{\circ} \mathrm{C}$ for sufficient time to deliver samples from Sydney to researchers anywhere. When dewars returned to Sydney which sometimes created long delays, the Australian Quarantine Inspection Service (AQIS) even threatened to decontaminate dewars with liquid which would have destroyed a $\$ 2000$ dewar. It took quite a lot of persistence to get access to the head of Australia's AQIS and explain that our dewars were never used to transport animal tissue. That solved the problem. Collection, transportation and storage at temperatures completely prevented the degradation of sensitive biomolecules, such as RNA, and giant proteins like titin (the largest protein in the heart). Soon, reviewers of our manuscripts stopped assuming human tissue was degraded in any significant way. In fact, the tissue we collected in 1989 shows no sign of degradation in 2020 . The collection process is really most efficient when two members of the team are involved. Usually, these were students working on various aspects of heart failure. I am grateful to Tom Yeoh, Toby Trahair (Trahair et al. 1990; 1993), Desiree Berry, Masako Tsubakihara, Sean Lal and Amy Li, to mention just a few, many of whom went on to do Medicine and a PhD. I could not have managed without their assistance. To date, we have collaboratively published 143 papers in high-quality journals.

\section{What have we discovered?}

The SHB has made many contributions to our understanding of the molecular basis of human heart failure. Here, I briefly outline three examples:

There has been a long-running polemic over whether postnatal human cardiomyocytes can proliferate. We sent 36 samples to Bernhard Kühn's group (Harvard) of healthy SHB donors aged between 3 months and 65 years (Mollova et al. 2013; Polizzotti et al. 2015). They developed a novel method 
of isolating cardiomyocytes using a preliminary fixation followed by collagenase digestion. This yielded over $92 \%$ of cardiomyocytes. Using microscopy, they found that cardiomyocyte proliferation and growth contribute to heart development. They measured a 3.4-fold increase in the number of cardiomyocytes which was consistent with predictions based on cell cycle activity during childhood and young adolescence, suggesting that with treatment during this period it may be possible to stimulate cardiac repair.

The Sydney Heart Bank also contributed heart samples to the Jonas Frisén-Olaf Bergmann (Bergmann et al. 2015) laboratory in Stockholm, who took a very different approach to the question of proliferation. On April 26, 1986, the accident at the Chernobyl Nuclear Power Plant in northern Ukraine effectively resulted in pulse-labelling $\left({ }^{14} \mathrm{C}\right)$ all people born after 1986. This was an extensive analysis of not only the left ventricle but of all chambers of the heart. We contributed samples from some of our younger donor hearts but over 50 human hearts were examined. They concluded that cardiomyocyte numbers do not appreciably change soon after birth and that changes in heart mass can be accounted for by hypertrophy remaining constant throughout the human lifespan, with a low turnover rate. Cardiac endothelial cell turnover was greater than $15 \%$ per year. Turnover of mesenchymal cells was also appreciable ( $<4 \%$ year in adults), but the exchange rate for cardiomyocyte is highest in babies and children and their numbers increase into adulthood to $<1 \%$. We will need new ideas and new techniques to determine which lab is correct.

1. The second example deals with a different but equally fundamental question. Hypertrophic cardiomyopathy (HCM) is the most common familial disease, and more than one-third of these patients carry a mutation in myosin heavy chain 7 (MYH7). While the severity of the phenotype depends on the location of the mutation in the MYH7 gene, it also depends on the fraction of mutated vs wildtype protein expressed. Theresia Kraft and her colleagues from the laboratory of the Late Bernard Brenner (Hannover) reported a surprising result. Using left ventricle samples from HCM patients, they measured contractile force in isolated single cardiomyocytes and found large cell-to-cell differences in $\mathrm{Ca}$-induced contraction (Montag et al. 2018). They also characterised gene transcription by visualising active transcription of intronic and exonic sequences of MYH7-pre-mRNA (Montag et al. 2018). Some cardiomyocytes were essentially the same, as healthy donors suggested they expressed no mutated MYH7 RNA. In total, $27 \%$ of myocyte nuclei were without active transcription sites and this was inconsistent with a continuous transcription mechanism. However, it was consistent with a burst-like transcription of mutant where wild-type alleles result in some myocytes having a completely wild-type expression, while adjacent cells had a completely hypertrophic phenotype (Montag et al. 2018). These reports ring "alarm bells" when attempting to phenotype from analyses of bulk heart tissue.

2. My third example arose in a curious way. We had been collaborating with Michael Ackerman and Martijn Bos (Mayo Clinic) for nearly a decade but we puzzled over the meaning of the data, so we decided to not publish. Then, in February, when COVID-19 became hot news, they remembered that ACE2 was the single largest upregulated $(\times 3.5)$ gene and was the most $(\times 5)$ upregulated protein. The connection to COVID-19 and heart complications suddenly became clearer because ACE2 is the membrane receptor through which SARS-CoV-2 enters cardiomyocytes, thus conferring an increased risk of cardiac involvement in COVID-19. The paper (Bos et al. 2020) was quickly accepted, but it illustrates how good science is never wasted.

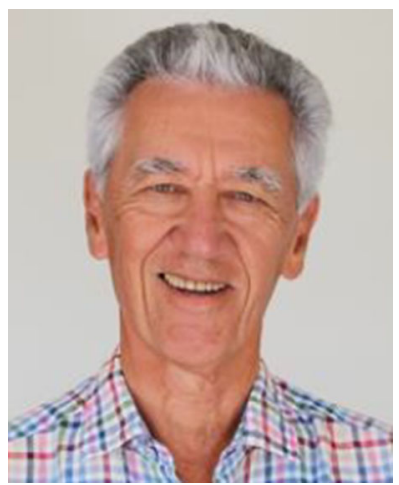

\section{References}

Bergmann O, Zdunek S, Felker A, Salehpour M, Alkass K, Bernard S, Szewczykowska M, dos Remedios C, Malm T, Nyengaard R, Possnert G, Jovinge S, Klinikapediatrii K, Sjos S, Jashari R, Druid H, Andrae M, Frisén J (2015) Dynamics of cell generation and turnover in the human heart. Cell 161:1566-1575. https://doi.org/ 10.1016/j.cell.2015.05.026

Bos JM, Hebl VB, Oberg AL, Sun Z, Herman DS, Teekakirikul P, Seidman JG, Seidman CE, dos Remedios CG, Maleszewski JJ, Schaff HV, Dearani JA, Noseworthy PA, Friedman PA, Ommen SR, Brozovich FV, Ackerman MJ (2020) Marked up-regulation of ACE2 in hearts of patients with obstructive hypertrophic cardiomyopathy: implications for SARS-CoV-2-mediated COVID-19. Mayo Clin Proc. https://doi.org/10.1016/j.mayocp.2020.04.028

Comroe J (1965) The lung. Year Book Medical.

dos Remedios CG, Chhabra D (2007) Actin and actin-binding proteins in human disease. Springer, New York, p 334

dos Remedios CG, Dickens MJ (1978) Actin microcrystals and tubes formed in the presence of gadolinium ions. Nature 276:731-733

dos Remedios CG, Moens PDJ (1995) Fluorescence resonance energy transfer spectroscopy is a reliable "ruler" for measuring structural changes in proteins - dispelling the problem of the unknown orientation factor. J Struct Biol 115:175-185 
dos Remedios CG, Millikan RGC, Morales MF (1972) Polarization of tryptophan fluorescence from single striated muscle fibres. A molecular probe of contractile state. J Gen Physiol 59:103-120

Kabsch W, Mannherz HG, Suck D, Pai EF, Holmes KC (1990) Atomic structure of the actin: DNase I complex. Nature 347:37-44

Mollova M, Bersell K, Walsh S, Savla J, Das LT, Park SY, Silberstein LE, dos Remedios CG, Graham D, Colan S, Kühn B (2013) Cardiomyocyte proliferation contributes to heart growth in young humans. Proc Natl Acad Sci USA. 110:1446-1451

Montag J, Syring M, Becker E, Rose J, Weber A-L, Ernstberger P, Mayer A-K, Keyser B, Perrot FAA, dos Remedios C, van der Velden J, Ho CY, Navarro-Lopez F, Brenner B, Kraft T (2017) Intrinsic MYH7 expression regulation contributes to tissue level allelic imbalance in hypertrophic cardiomyopathy. J Muscle Res Cell Motil. 38:291-302

Montag J, Kowalski K, Makul M, Ernstberger P, Radocaj A, Beck BJE, Tripathi S, Keyser B, Mühlfeld C, Wissel K, Pich A, van der Velden J, dos Remedios CG, Perrot A, Francino A, Navarro-Lopez F, Brenner B, Kraft T (2018) Burst-like transcription of mutant and wildtype MYH7-alleles as possible origin of cell-to-cell contractile imbalance in hypertrophic cardiomyopathy. Front Physiol 9:358. https://doi.org/10.3389/fphys.2018.00359

Polizzotti BD, Ganapathy B, Walsh S, Choudhury S, Ammanamanchi N, Bennett DG, dos Remedios CG, Haubner BJ, Penninger JM, Kühn B (2015) Stimulation of cardiomyocyte regeneration in neonatal mice and in human myocardium with neuregulin reveals a therapeutic window. Sci Transl Med 7:281ra45. https://doi.org/10.1126/ scitranslmed.aaa5171

Trahair T, Yeoh T, Cartmill T, Chang V, Gunning P, dos Remedios CG (1990) Is atrial myosin light chain 1 a marker of end stage failure in dilated cardiomyopathy? In: Marechál M (ed) Cell motility. Intercept Press, Hampshire, pp 181-187

Trahair T, Yeoh T, Cartmill T, Keogh A, Spratt P, Chang V, dos Remedios CG, Gunning P (1993) Myosin light chain gene expression associated with diseased states of the human heart. J Mol Cell Cardiol 26:577-585

Publisher's note Springer Nature remains neutral with regard to jurisdictional claims in published maps and institutional affiliations. 